Article

\title{
Evaluation of Some Postharvest Storage Approaches on Essential Oil Characteristics of Fresh Organic Damask Rose (Rosa damascena Mill.) Flowers
}

\author{
Maryam Mirzaei ${ }^{1}$, Nima Ahmadi ${ }^{1, *}$, Fatemeh Sefidkon ${ }^{2}$, Abdolali Shojaeiyan ${ }^{1}$ and \\ Alireza Mazaheri ${ }^{3}$ \\ 1 Department of Horticultural Sciences, Tarbiat Modares University, Tehran 336-14115, Iran; \\ maryammirzaeem@gmail.com (M.M.); shoja_a@yahoo.com (A.S.) \\ 2 Research Institute of Forests and Rangelands, Tehran 13185-116, Iran; sefidkon@rifr-ac.ir \\ 3 R \& D Department, Golkaran Essential Oils and Herbal Extracts Company, Kashan 1178, Iran; \\ mazaheri_58@yahoo.com \\ * Correspondence: ahmadin@modares.ac.ir; Tel.: +98-21-4829-2088; Fax: +98-21-4829-2200
}

Academic Editors: Varit Srilaong, Mantana Buanong, Chalermchai Wongs-Aree, Sirichai Kanlayanarat and Douglas D. Archbold

Received: 4 December 2015; Accepted: 27 July 2016; Published: 30 December 2016

\begin{abstract}
Damask rose (Rosa damascena Mill.) is an economically important species in the Rosaceae family for rose oil and rose water production, obtained exclusively from freshly-gathered Damask rose flowers. Iran is famous for producing organic rose essential oil, mainly used in the perfume industry and for folk medicines due to its healing properties. Due to their high perishability, postharvest handling of the flowers prior to oil extraction are a key point in rose essential oil production. In this study, postharvest handling conditions of Damask rose flowers were evaluated for the effect on yield and quality of the extracted essential oils. Organically-grown flowers were stored under different conditions included packaging in polyethylene bags and immersing into water containers, and then held at $25 \pm 2{ }^{\circ} \mathrm{C}$ or $4 \pm 1{ }^{\circ} \mathrm{C}$ for 1,2 , or 3 days. Identification of the chemical composition of the essential oils was performed by GC and GC/MS. The results indicated that petal storage in water resulted in the highest essential oil content and quality, and storage in polyethylene bags resulted in the greatest loss, compared to those from unstored petals. The results provide a reference for interested groups such as producers and consumers who are concerned about Damask rose flower storage and subsequent oil extraction.
\end{abstract}

Keywords: essential oil characteristics; organic damask rose; post-harvest handling

\section{Introduction}

Rosa damascena Mill., commonly known as the oil-bearing rose, is one of the most important Rosa species cultivated for production of rose oil and rose water [1]. Rose oil, one of the most expensive base materials in the flavor and perfume industries, is characterized by a high percentage of monoterpene alcohols including citronellol, nerol, geraniol, linalool, and phenyl ethyl alcohol. These components are the main contributors to the perfume value of rose oil [2]. According to the international standard of rose essential oil [3], rose oil requires 20\%-34\% citronellol, 15\%-22\% geraniol, and $8 \%-15 \%$ nonadecane as the main compounds [3]. As harvested Damask rose flowers are highly perishable, postharvest handling of the flowers prior to oil extraction is a vital step in rose essential oil production. Due to the huge volume of Damask rose flowers delivered to the factories during the harvest period, it often takes a long time before flowers are eventually extracted and distilled. Excessive temperatures inside the stacks of harvested flowers caused by their high respiration rate results in losses of essential oil quantity and quality [2]. Providing optimal storage conditions throughout postharvest handling 
could reduce losses of yield and quality of essential oils [4,5]. The high value of the essential oil of Damask rose is an important reason for finding proper storage techniques for the flower crop after harvest. Therefore, the objectives of this study were to determine the effects of ambient and reduced temperatures as well as different storage durations and surrounding mediums on the yield and chemical components of organic Damask rose flowers throughout a postharvest handling period of 3 days.

\section{Experimental Section}

\subsection{Plant Material}

Organically-grown fresh Damask roses petals were handpicked from a Rosarium located in Mashhad-e Ardehal, Kashan, Iran, and transported immediately to the laboratory. The essential oils obtained from unstored petals (0 day storage duration), which were hydrodistilled shortly after harvest, were considered as the reference point in order to determine the effect of storage conditions on essential oil content and oil composition.

\subsection{Storage Conditions}

The petals were stored under the following conditions: packaged using sealed polyethylene (PE) bags ( $60 \mu \mathrm{m}$ thick), or immersed in water inside sealed plastic containers $(20 \mathrm{~cm} \times 25 \mathrm{~cm} \times 30 \mathrm{~cm}$ ), and then held at $25^{\circ} \mathrm{C}\left(25 \pm 2{ }^{\circ} \mathrm{C}, 45 \% \pm 5 \% \mathrm{RH}\right)$ or $4{ }^{\circ} \mathrm{C}\left(4 \pm 1{ }^{\circ} \mathrm{C}, 90 \% \pm 5 \% \mathrm{RH}\right)$ for 1,2 and 3 days.

\subsection{Essential Oil Extraction}

The essential oil was extracted from $250 \mathrm{~g}$ petals by hydrodistillation with $750 \mathrm{~mL}$ of distilled water using a $4 \mathrm{~L}$ Clevenger-type apparatus for each experimental replication. The distillation time was $1.5 \mathrm{~h}$ and the oil content was measured as percentage $(v / w \%)$. In the case of the water storage method, the water used for storage was also hydrodistilled.

\subsection{Characterization of Essential Oil Components}

\subsubsection{Gas Chromatography (GC)}

The essential oils were analyzed on a Thermo-UFM (Ultra-fast model, Milan, Italy) gas chromatograph using a $10 \mathrm{~m} \times 0.1 \mathrm{~mm}$ capillary column PH-5 (nonpolar), with an inner surface with a stationary phase of $5 \%$ dimethyl siloxane phenyl. The oven temperature was held at $60{ }^{\circ} \mathrm{C}$ for $3 \mathrm{~min}$, programmed to $285^{\circ} \mathrm{C}$ at the rate of $80^{\circ} \mathrm{C} / \mathrm{min}$, and detector (FID) and injection chamber temperatures were $280^{\circ} \mathrm{C}$. Helium was used as the carrier gas with inlet pressure of $0.5 \mathrm{~mL} / \mathrm{min}$.

\subsubsection{Gas Chromatography-Mass Spectrometry (GC-MS)}

The GC-MS analysis was performed using a Varian 3400 gas chromatograph connected to a mass spectrometer model Saturn II, using an ion trap system having ionization energy of $70 \mathrm{eV}$, with a DB-5 column (semi-polar), with dimensions of $30 \mathrm{~m} \times 0.25 \mathrm{~mm}$, and a film thickness $0.25 \mathrm{~mm}$. Gas pressure was $2.46 \mathrm{~kg} / \mathrm{cm}^{2}$, column temperature was 40 to $250{ }^{\circ} \mathrm{C}$ with a rate of increase of $3{ }^{\circ} \mathrm{C} / \mathrm{min}$, and the injection chamber temperature and the transfer line were set at $260{ }^{\circ} \mathrm{C}$ and $270{ }^{\circ} \mathrm{C}$, respectively. The carrier gas was helium with a linear velocity of $31.5 \mathrm{~cm} / \mathrm{s}$, and a split ratio of 1:60. A scan time of $1 \mathrm{~s}$ with a mass range 40-300 were used. Spectra identification were carried out using retention indices and by injection of normal hydrocarbons (C7-C25) under the same conditions and confirmed with the Wiley 275-L library and the data reported in the literature [6-8].

\subsection{Data Analysis}

The experiment was carried out as a factorial with the factors of storage duration, petal storage medium, and storage temperature in a randomized complete block design (RCBD). There were 
three replications of essential oil extraction from the petals for every treatment combination. Analysis of data from the essential oil content was performed using the general linear model (GLM) of SAS 9.2 [9]. Mean values were compared at the $5 \%(p \leq 0.05)$ and $1 \%(p \leq 0.01)$ levels of significance using Fisher's Least Significant Difference (LSD) test. There were three replications of every treatment combination. Component analyses of the oils were performed by injecting a mix of the three replications of each treatment combination on both GC and GC/MS.

\section{Results and Discussion}

\subsection{Essential Oil Contents}

The petal essential oil content was significantly affected by storage condition and duration, but not temperature alone. There was a significantly greater content of essential oil stored in water at $4{ }^{\circ} \mathrm{C}$ and $25^{\circ} \mathrm{C}$ at 1, 2 and 3 day compared to petals stored in PE bags (Figure 1). Storage of flowers in water recorded a significant increase $(p \leq 0.01)$ of $16 \%, 19 \%$ and $23 \%$ in essential oil content after 1,2, and 3 day, respectively, over the unstored petals with an average value of $0.069(v / w \%)$. This increase could be explained by considering the limitation of $\mathrm{O}_{2}$ inside the containers along with the presence of water that may have caused fermentation, as it has been indicated that rose petals produce more essential oil with a fermentation period after harvest [10]. The mean essential oil content obtained from petals stored in PE for 1 day were close to the value at harvest (unstored petals) but were significantly lower after 2 or 3 day of storage. Cold-stored flowers in water contained higher oil content than those in PE at the same storage temperature, which might be explained by the ability of water to maintain volatile oil content of the petals during the storage period, while the permeability of the PE bags might result in losses from volatilization of essential oils, particularly with the extension of the storage period.

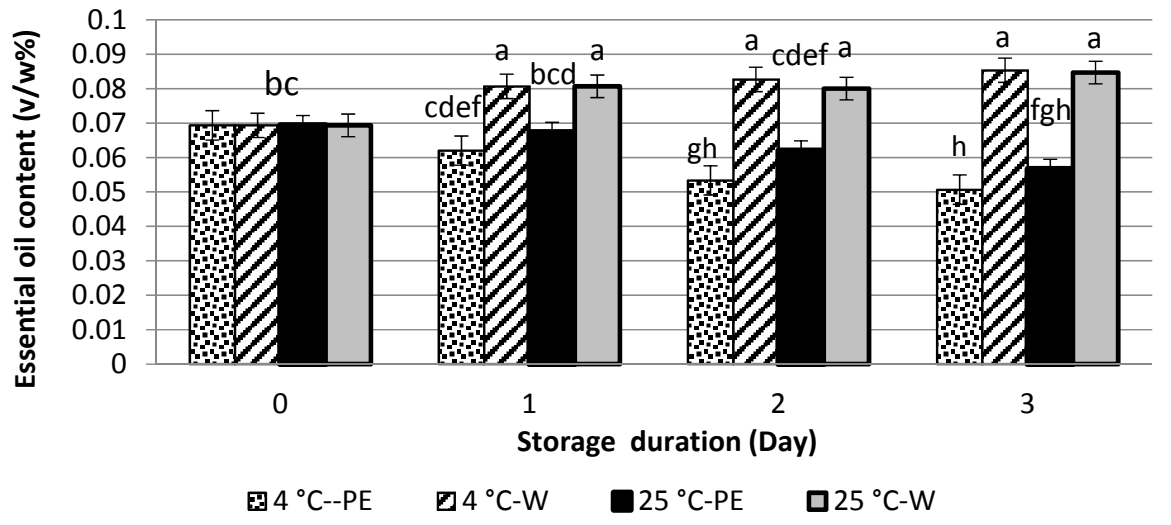

Figure 1. Mean essential oil content $(v / w \%$, fresh weight basis) of organic Damask rose under different storage conditions. PE: (Polyethylene bag); W: (Water).

\subsection{The Essential Oil Components}

The changing patterns of the essential oil components under the storage conditions indicated that the chemical profile of rose oil throughout storage of petals in PE bags was affected more than storage in water under either $25^{\circ} \mathrm{C}$ or $4{ }^{\circ} \mathrm{C}$ storage conditions, with a higher degradation of geraniol in favor of citronellol at $25^{\circ} \mathrm{C}$ (Table 1). Storage of petals in water impacted the maintenance of the major essential oil compounds. The component analyses of oils from 2 and 3 day samples indicated that storage of the petals in the cold water $\left(4^{\circ} \mathrm{C}-\mathrm{W}\right)$ maintained the rose oil characteristics better than the other handling method, with approximately $38 \%$ lower levels of long-chain aliphatic hydrocarbons after 1 day of storage, which resulted in improvement of the oil quality. A possible reason for the rise of monoterpene alcohols might be ascribed to the proper conditions for the action of enzymes, such as $\beta$-glucosidase involved in hydrolysis and liberation of monoterpene alcohols from their glycosidic forms [11]. 
Table 1. Damask rose essential oil components under different storage conditions.

\begin{tabular}{|c|c|c|c|c|c|c|c|c|c|c|c|c|c|c|c|c|c|}
\hline & ors of Variance & 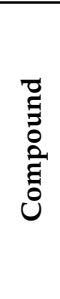 & 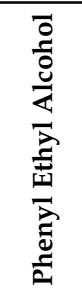 & 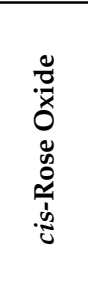 & 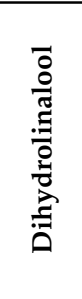 & 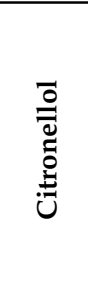 & $\begin{array}{l}\bar{\pi} \\
\text { Z }\end{array}$ & 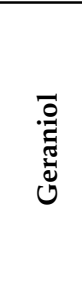 & 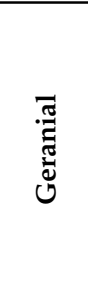 & 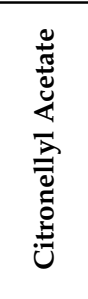 & 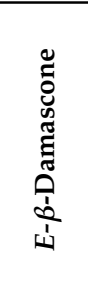 & 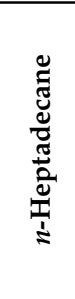 & 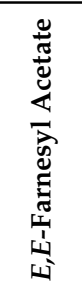 & 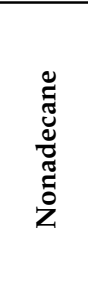 & 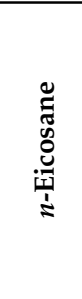 & 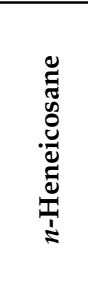 & 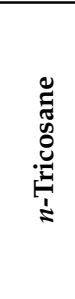 \\
\hline Time & Storage conditions & RI & 1109 & 1113 & 1135 & 1228 & 1240 & 1255 & 1269 & 1355 & 1416 & 1693 & 1728 & 1902 & 2003 & 2102 & 2298 \\
\hline 0 day & Unstored petals & & 1.3 & 0.3 & 0.8 & 35.5 & 13.3 & 16.8 & 3.1 & 0.4 & 0.2 & 2.3 & 1.1 & 15.6 & 0.7 & 2.6 & 0.8 * \\
\hline 1 day & $\begin{array}{c}4{ }^{\circ} \mathrm{C}-\mathrm{PE} \\
4^{\circ} \mathrm{C}-\mathrm{W} \\
25^{\circ} \mathrm{C}-\mathrm{PE} \\
25^{\circ} \mathrm{C}-\mathrm{W}\end{array}$ & & $\begin{array}{l}1.0 \\
1.3 \\
1.6 \\
1.1\end{array}$ & $\begin{array}{l}0.3 \\
0.3 \\
0.4 \\
0.7\end{array}$ & $\begin{array}{l}0.8 \\
0.9 \\
1.3 \\
0.9\end{array}$ & $\begin{array}{l}42.5 \\
38.2 \\
47.4 \\
42.3\end{array}$ & \begin{tabular}{c|}
3.9 \\
21.5 \\
16.5 \\
11.4
\end{tabular} & $\begin{array}{c}13.0 \\
13.4 \\
9.8 \\
12.6\end{array}$ & $\begin{array}{l}0.3 \\
2.9 \\
5.8 \\
2.0\end{array}$ & $\begin{array}{c}- \\
0.2 \\
- \\
0.1\end{array}$ & $\begin{array}{c}- \\
0.3 \\
0.3 \\
0.4\end{array}$ & $\begin{array}{l}2.3 \\
2.5 \\
2.6 \\
2.9\end{array}$ & $\begin{array}{l}0.2 \\
0.9 \\
0.4 \\
0.7\end{array}$ & $\begin{array}{c}17.9 \\
9.1 \\
8.8 \\
20.5\end{array}$ & $\begin{array}{l}1.4 \\
0.5 \\
0.3 \\
1.0\end{array}$ & $\begin{array}{l}8.1 \\
1.0 \\
4.1 \\
6.3\end{array}$ & $\begin{array}{l}1.2 \\
0.3 \\
0.8 \\
0.9\end{array}$ \\
\hline 2 days & $\begin{array}{c}4{ }^{\circ} \mathrm{C}-\mathrm{PE} \\
4^{\circ} \mathrm{C}-\mathrm{W} \\
25^{\circ} \mathrm{C}-\mathrm{PE} \\
25^{\circ} \mathrm{C}-\mathrm{W}\end{array}$ & & $\begin{array}{l}0.9 \\
1.7 \\
1.2 \\
1.1\end{array}$ & $\begin{array}{l}0.4 \\
0.5 \\
0.3 \\
1.1\end{array}$ & $\begin{array}{l}0.8 \\
1.4 \\
0.5 \\
1.1\end{array}$ & $\begin{array}{l}45.6 \\
48.2 \\
36.5 \\
43.4\end{array}$ & $\begin{array}{l}12.5 \\
15.6 \\
18.7 \\
10.2\end{array}$ & $\begin{array}{c}10.8 \\
8.1 \\
10.0 \\
11.8\end{array}$ & $\begin{array}{l}1.6 \\
6.2 \\
2.0 \\
1.2\end{array}$ & $\begin{array}{c} \\
- \\
0.2 \\
-\end{array}$ & $\begin{array}{l}0.4 \\
0.3 \\
0.1 \\
0.6\end{array}$ & $\begin{array}{l}2.6 \\
2.8 \\
2.6 \\
3.3\end{array}$ & $\begin{array}{l}0.5 \\
0.7 \\
0.5 \\
0.4\end{array}$ & $\begin{array}{c}18.9 \\
7.3 \\
12.8 \\
22.2\end{array}$ & $\begin{array}{l}2.1 \\
0.4 \\
0.4 \\
1.1\end{array}$ & $\begin{array}{c}12.3 \\
0.6 \\
1.7 \\
5.0\end{array}$ & $\begin{array}{l}2.2 \\
0.8 \\
0.5 \\
1.1\end{array}$ \\
\hline 3 days & $\begin{array}{c}4{ }^{\circ} \mathrm{C}-\mathrm{PE} \\
4{ }^{\circ} \mathrm{C}-\mathrm{W} \\
25^{\circ} \mathrm{C}-\mathrm{PE} \\
25^{\circ} \mathrm{C}-\mathrm{W}\end{array}$ & & $\begin{array}{l}1.0 \\
0.7 \\
1.9 \\
1.0\end{array}$ & $\begin{array}{l}0.3 \\
0.4 \\
0.6 \\
1.5\end{array}$ & $\begin{array}{l}0.7 \\
1.0 \\
0.8 \\
1.4\end{array}$ & $\begin{array}{l}47.4 \\
35.6 \\
36.5 \\
46.7\end{array}$ & $\begin{array}{c}7.4 \\
16.4 \\
12.8 \\
9.2\end{array}$ & $\begin{array}{c}9.0 \\
15.4 \\
5.2 \\
10.0\end{array}$ & $\begin{array}{l}0.6 \\
3.4 \\
5.9 \\
0.9\end{array}$ & $\begin{array}{l}- \\
- \\
-\end{array}$ & $\begin{array}{c}- \\
0.4 \\
0.2 \\
0.8\end{array}$ & $\begin{array}{l}2.9 \\
3.1 \\
3.4 \\
3.9\end{array}$ & $\begin{array}{l}- \\
- \\
0.8 \\
0.1\end{array}$ & $\begin{array}{c}20.7 \\
7.6 \\
12.6 \\
23.6\end{array}$ & $\begin{array}{l}2.7 \\
0.6 \\
0.4 \\
1.2\end{array}$ & $\begin{array}{c}14.3 \\
2.2 \\
3.6 \\
4.6\end{array}$ & $\begin{array}{l}4.1 \\
0.4 \\
0.7 \\
1.3\end{array}$ \\
\hline
\end{tabular}

RI: Retention Index; ${ }^{*}$ Relative percentage of each component in relation to total essential oil; W: water; PE (polyethylene). 


\section{Conclusions}

As the water used for the storage of the flowers was then used in the hydrodistillation, water, particularly at low temperatures, might be an effective storage method for oil-bearing rose petals after harvest to maintain essential oil content and component quantities close to the content of freshly-harvested flowers. These results are useful for choosing the best storage techniques for Damask rose flowers prior to processing.

Acknowledgments: The authors would like to express their appreciation to Barij Essence Company for their support and for providing facilities for this study.

Author Contributions: Maryam Mirzaei, Nima Ahmadi, Fateme Sefidkon and Abdolali Shojaeiyan designed the research; Maryam Mirzaei, Nima Ahmadi and Fateme Sefidkon performed the research; Nima Ahmadi, Fateme Sefidkon, Alireza Mazaheri and Abdolali Shojaeiyan contributed analysis tools/materials/reagents; Maryam Mirzaei analyzed the data; Maryam Mirzaei and Nima Ahmadi wrote the paper.

Conflicts of Interest: The authors declare no conflict of interest.

\section{References}

1. Widrlechner, M.P. History and utilization of Rosa damascena. Econ. Bot. 1981, 35, 42-58. [CrossRef]

2. Baydar, H.; Baydar, N. The effects of harvest date, fermentation duration and Tween 20 treatment on essential oil content and composition of industrial oil rose (Rosa damascena Mill.). Ind. Crops Prod. 2005, 21, 251-255. [CrossRef]

3. Oil of Rose (Rosa $\times$ damascena Mill.). International Standards for Business, Government and Society. Available online: http:/ /www.iso.org (accessed on 10 August 2015).

4. Najafian, S. Storage conditions affect the essential oil composition of cultivated Balm Mint Herb (Lamiaceae) in Iran. Ind. Crops Prod. 2014, 52, 575-581. [CrossRef]

5. Kazaz, S.; Sabri, E.; Baydar, H.; Dilmacunal, T.; Koyuncu, M.A. Cold storage of oil rose (Rosa damascena Mill.) flowers. Sci. Hortic. 2010, 126, 284-290. [CrossRef]

6. Adams, R.P. Identification of Essential Oils by Ion Trap Mass Spectroscopy; Academic Press: New York, NY, USA, 1989; p. 302.

7. Shibamoto, T. Retention Indices in Essential Oil Analysis in Capillary Gas Chromatography in Essential Oil Analysis; Sandra, P., Bicci, C., Eds.; Verlag: New York, NY, USA, 1987; pp. 259-274.

8. McLafferty, F.W.; Stauffer, D.B. The Wiley/NBS Registry of Mass Spectral Data; Wiley and Sons: New York, NY, USA, 1989.

9. $\quad$ SAS Institute Inc. SAS Online Doc ${ }^{\circledR}$ 9.2; SAS Institute Inc.: Cary, NC, USA, 2008.

10. Menary, R.; Mactavish, H.S. Rural industries research and development corporation. In Boronia Extraction: Increasing Yield and Quality: A Report for the Rural Industries; Research and Development Corporation: Hobart, Australia, 2000.

11. Baldermann, S.; Yang, Z.; Sakai, M.; Fleischmann, P.; Watanabe, N. Volatile constituents in the scent of roses. Floric. Ornam. Biotechnol. 2009, 3, 89-97.

(C) 2016 by the authors; licensee MDPI, Basel, Switzerland. This article is an open access article distributed under the terms and conditions of the Creative Commons Attribution (CC-BY) license (http://creativecommons.org/licenses/by/4.0/). 